\title{
Ability of lactoferrin to promote the growth of Bifidobacterium spp. in vitro is independent of receptor binding capacity and iron saturation level
}

\author{
BRYON W. PETSCHOW, ROBERT D. TALBOTT and ROSANNE P. BATEMA \\ Mead Johnson Research Center, Bristol-Myers Squibb Co., 2400 W. Lloyd Expressway, Evansville, IN 47721, \\ USA
}

Lactoferrin (Lf) is an iron-binding protein which has been shown to inhibit the growth of various bacterial pathogens and promote the growth of anaerobic bacteria of the genus Bifidobacterium in vitro. The present study was designed to investigate whether the bifidobacteria growth promotion activity of $\mathrm{Lf}$ is correlated with either the binding of Lf to bifidobacterial cells or the iron saturation of Lf. Bovine Lf (bLf) from mature milk increased the growth of $B$. infantis and $B$. breve in vitro in a dose-dependent fashion, while much less growth promotion activity was found for $B$. bifidum. In contrast, human Lf (huLf) from mature milk promoted the growth of $B$. bifidum and was inactive for $B$. infantis and $B$. breve, while bLf from colostrum was devoid of bifidobacteria growth promotion activity. Changes in the iron content of Lf did not alter the bifidobacteria growth promotion activity of either bLf or huLf preparations. Competitive binding studies with biotinylated milk bLf showed that binding of bLf was inhibited by unlabelled bLf and huLf but not by $\beta$-lactoglobulin, $\alpha$-lactalbumin or transferrin. Binding of bLf to $B$. bifidum and $B$. breve was $c$. 40 -fold higher than binding to Escherichia coli. Colostrum bLf was also found to bind to $B$. bifidum and $B$. breve, despite a lack of in-vitro growth promotion activity. Collectively, these results demonstrate that the ability of Lf to promote the growth of Bifidobacterium spp. in vitro is independent of the iron saturation level for $\mathrm{Lf}$ and suggest that binding of $\mathrm{Lf}$ to bifidobacteria cells may be involved but is not sufficient for stimulation of bifidobacterial growth.

\section{Introduction}

The ability of pathogenic bacteria to survive and proliferate within the gastrointestinal tract of the host is determined by a number of host and microbial factors. The host's diet may be of particular importance, because dietary constituents can impact both the nutritional status of the host and the indigenous bacterial flora that reside in the intestinal tract. Dietary components may also inhibit enteric bacterial pathogens either directly due to the inhibitory activity of specific food components, or indirectly because of dietinduced changes in the composition and metabolism of the non-pathogenic indigenous flora. Such changes in the indigenous bacterial flora may either encourage or discourage the proliferation and colonisation of mucosal surfaces by enteric pathogens.

Received 3 Sept. 1997; revised version received 13 July 1998; accepted 21 Sept. 1998.

Corresponding author: Dr B. W. Petschow.
Anaerobic bacteria of the genus Bifidobacterium are frequently reported as one of the predominant organisms found in the faeces of breast-fed infants. More importantly, bifidobacteria are believed to be a beneficial component of the indigenous flora of the infant because of their ability to produce acetic and lactic acids which may discourage pathogenic bacteria $[1,2]$. A number of studies have reported differences in the number and types of bifidobacteria in faeces of breast-fed and formula-fed infants [3-7], leading to the suggestion that such differences are partly responsible for the lower incidence of intestinal infections and diarrhoea observed among breast-fed infants in both developed and underdeveloped countries [8-11]. However, the mechanisms that account for differences in the composition of the intestinal flora and susceptibility to diarrhoeal disease among breast-fed and formula-fed infants have not been determined.

Human milk contains a number of factors that are known to have antimicrobial activity in various in- 
vitro systems. Furthermore, human milk has been shown to contain specific substances that promote the growth of bifidobacteria in vitro [12-16]. These observations have led to widespread assumptions that such antibacterial factors play a role in protecting the infant from diarrhoeal disease caused by certain intestinal pathogens [17-19]. Lactoferrin (Lf) is an iron-binding glycoprotein found in milk and various mucosal secretions that has been shown to inhibit the growth of Escherichia coli and other bacteria in vitro [20-23]. Surprisingly, earlier studies [16] found that Lf from cow's milk promoted the growth of bifidobacteria in vitro. These results suggest that Lf may have dual mechanisms for inhibiting enteric bacterial pathogens through direct inhibition of bacterial growth or development of favourable changes in the composition and metabolism of the non-pathogenic indigenous intestinal bacteria. Because the Lf molecule is capable of binding iron, it is reasonable to assume that the growth stimulatory activity of Lf for Bifidobacterium spp. may be related to iron acquisition or utilisation by bifidobacterial cells. Accordingly, the present study was conducted to determine whether the growth promotion activity of $\mathrm{Lf}$ for strains of Bifidobacterium spp. is directly correlated with the iron saturation level of the $\mathrm{Lf}$ or the quantitative binding of $\mathrm{Lf}$ by bifidobacteria cells.

\section{Materials and methods}

\section{Bacterial strains}

Strains of bifidobacteria used in this study were purchased in lyophilised form from the American Type Culture Collection (Rockville, MD, USA). These strains included the following human faecal isolates: $B$. bifidum ATCC 15696, B. infantis ATCC 15697 and B. breve ATCC 15700. Cultures were grown in pre-reduced Reinforced Clostridial Medium (RCM; Difco Laboratories, Detroit, MI, USA) supplemented with $\mathrm{KH}_{2} \mathrm{PO}_{4}$ $(4.5 \mathrm{~g} / \mathrm{L})$ and $\mathrm{Na}_{2} \mathrm{HPO}_{4}(6.0 \mathrm{~g} / \mathrm{L})$ at $37^{\circ} \mathrm{C}$ under anaerobic conditions (GasPak jars; BBL Microbiology Systems, Cockeysville, MD, USA). Numbers of viable bifidobacterial cells were quantified by standard plate counting methods with RCM agar plates and prereduced dilution medium (20 mM phosphate buffer containing agar $0.05 \%$, cysteine- $\mathrm{HCl} 0.05 \%, \mathrm{pH} 6.8$ ).

\section{Materials}

Bovine colostrum was obtained during first and second milkings and immediately frozen $\left(-75^{\circ} \mathrm{C}\right)$ until used for Lf isolation. Lactoferrin was isolated from unpasteurised human milk, bovine milk and bovine colostrum by cation-exchange chromatography as described previously [24]. Briefly, frozen samples of milk or colostrum were thawed overnight at $4^{\circ} \mathrm{C}$, skimmed by centrifugation at $5000 \mathrm{~g}\left(20^{\circ} \mathrm{C}, 30 \mathrm{~min}\right)$ and eluted through a cation-exchange resin (Fast-S; Pharmacia, Piscataway, NJ, USA) with $20 \mathrm{~mm}$ sodium phosphate buffer to separate bound Lf from unbound proteins. Bound Lf was released from solid phase support with a linear gradient of $\mathrm{NaCl}(0-2.0 \mathrm{M})$ in $20 \mathrm{mM}$ phosphate buffer ( $\mathrm{pH} 7.5)$ and desalted by exhaustive diafiltration through a YM10 membrane (Amicon, Danvers, MA, USA) against cold saline. Final Lf preparations were filter sterilised (Gelman Sciences, Ann Arbor, MI, USA) and stored in $1-\mathrm{ml}$ volumes $(\sim 15 \mathrm{~g} / \mathrm{L})$ at $-20^{\circ} \mathrm{C}$. Samples of $\mathrm{Lf}$ from fresh mature human milk and cow milk were also prepared by the same method followed by a subsequent purification step with a Mono-S cation-exchange column (Pharmacia) and kindly provided by $\operatorname{Dr} J$. Nuijens (Gene Pharming Europe BV, Leiden, The Netherlands). Samples of a commercial preparation of Lf from mature cow milk were obtained from AlaPharm (Palmerston North, New Zealand). Native and iron-saturated forms of human transferrin (huTf) were obtained from Sigma. Protein levels in Lf preparations were determined by a modification of the method of Lowry [25] with bovine Lf as protein standard following calibration by Kjeldahl protein measurement. Purity of Lf preparations was assessed by competitive antibody capture ELISA and SDS-PAGE. The iron saturation level of Lf preparations was determined spectrophotometrically by an increase in the ratio of $\mathrm{A}_{280}$ versus $\mathrm{A}_{465}$ [26]. Lipopolysaccharide (LPS) of Lf preparations was determined by quantitative Limulus assay (KineticQCL, BioWhittaker).

Bovine Lf obtained from Alapharm showed a purity of c. $78 \%$ while the purity of bLf and huLf samples prepared by ion-exchange chromatography was consistently $>97 \%$ (Table 1). Attempts to further purify the commercial $\mathrm{Lf}$ sample were unsuccessful due to co-elution of several contaminating proteins with Lf. The iron saturation level of experimental Lf samples was $18 \%$ for the commercial bLf sample (Alapharm) and $3-6 \%$ for the colostrum bLf, milk bLf and milk huLf. The LPS content of the commercial bLf preparation was also much higher than the LPS content of Lf samples prepared by ion exchange (Table 1).

Table 1. Biochemical characteristics of experimental lactoferrin preparations

\begin{tabular}{lccr}
\hline & $\begin{array}{c}\text { Purity } \\
\text { Lf sample* }\end{array}$ & $\begin{array}{c}\text { LPS } \\
\text { Iron saturation } \\
\text { level (\%) }\end{array}$ & $\begin{array}{r}\text { content } \\
(\mathrm{EU} / \mathrm{mg})^{\ddagger}\end{array}$ \\
\hline Bovine colostrum (bLf) & 98 & 7 & 15.0 \\
Bovine milk (bLf) & 98 & 3 & $<1.0$ \\
Bovine milk (commercial bLf) & 78 & 18 & 1599.0 \\
Human milk (huLf) & 99 & 6 & $<1.0$ \\
\hline
\end{tabular}

*Experimental samples included Lf isolated from unpasteurised bovine colostrum, bovine milk and human milk, or a commercial preparation of milk bLf (Alapharm).

Determined by indirect ELISA and SDS-PAGE.

${ }^{\ddagger}$ Represents the amount of LPS in Lf preparations in endotoxin units (EU) as measured by Limulus assay/mg Lf protein. 


\section{Bifidobacteria growth promotion assay}

The growth promotional activity of test protein samples for strains of bifidobacteria was measured by the method of Bezkorovainy et al. $[12,14]$ as described previously [15]. Briefly, pre-reduced basal Norris medium containing diluent of Lf test samples was inoculated with test strains of bifidobacteria $c .5 \times 10^{5}$ cfu/ $0.1 \mathrm{ml}$ ) in a total volume of $4 \mathrm{ml}$ and incubated anaerobically for $48 \mathrm{~h}$ at $37^{\circ} \mathrm{C}$. The final iron concentration of the assay mixture was estimated to be c. $0.8 \mu \mathrm{g} / \mathrm{ml}$. The amount of acid present in cellfree supernates after the 48 -h incubation period was measured as an indicator of bacterial growth and metabolism. Growth promotion activity was expressed in units defined as mmole of $\mathrm{NaOH}$ required to neutralise the acid produced in a 4-ml culture of the test strain after incubation for $48 \mathrm{~h}$. Control samples containing saline without protein test materials were included in all experiments. Previous studies established that a direct correlation exists between acid production by bifidobacteria and increases in viable cell numbers in the in-vitro growth promotion assay $[15,16]$. These studies also showed that acid production by bifidobacteria is a more reliable indicator of growth promotion activity than final increases in cell numbers, as different strains of bifidobacteria vary in sensitivity to the bactericidal effect of metabolic acids.

\section{Measurement of lactoferrin binding to bacterial cells}

Binding of Lf to bacterial cells was determined experimentally with biotinylated bLf and enzymeconjugated streptavidin. Briefly, biotinylated bLf (5$4000 \mathrm{ng})$ was mixed with washed bacterial cells $\left(\sim 10^{8} \mathrm{cfu}\right)$ in a total volume of $0.2 \mathrm{ml}$ and incubated at $22^{\circ} \mathrm{C}$ for $1 \mathrm{~h}$. Cell mixtures were then washed with $2 \mathrm{ml}$ of cold PBS/Tween 20 (2300 rpm for $10 \mathrm{~min}$ ) and resuspended in $0.5 \mathrm{ml}$ of wash buffer containing horseradish peroxidase (HRP)-labelled streptavidin. After incubation of $1 \mathrm{~h}$ at room temperature, cells were washed twice with PBS/Tween 20 (20 volumes) and resuspended in $500 \mu 1$ of wash buffer. Duplicate aliquots of washed cell suspensions were incubated with tetramethylbenzidine (TMB) and $\mathrm{H}_{2} \mathrm{O}_{2}$ to detect HRP activity $\left(\mathrm{ABS}_{450}\right)$ as an indicator of biotinylated Lf. Results represent the mean of at least duplicate determinations. Binding of bLf was adjusted for background binding by subtracting the absorbance of control tubes which contained test bacterial cells and HRP-streptavidin (no labelled Lf) in the absence of test bacterial cells. To evaluate the effect of specific and non-specific proteins on Lf binding, bacterial cells were pre-incubated with unlabelled proteins, washed three times in wash buffer and then tested for binding of biotinylated $\mathrm{Lf}$ as described.

Biotin labelling of test Lf samples was performed with a commercially available kit (Pierce Chemicals, Rockford, IL, USA). Biotin was chosen as the preferred method for labelling Lf in binding studies because the conditions for biotinylation are generally considered to be milder and less likely to result in structural changes in the Lf molecule than other methods. The level of biotinylation of $\mathrm{Lf}$ preparations was routinely c. 0.185 moles of biotin/mole $\mathrm{Lf}$, which was similar in both milk and colostrum bLf.

\section{Statistical methods}

Lactoferrin treatment effects on in-vitro growth of Bifidobacterium spp. were analysed by a one-way analysis of variance and Tukey's multiple comparison procedure (SAS/LAB PC version 6.08). Analysis of variance was also used to compare the overall response to Lf growth promotion activity by different bacterial strains. Differences were considered statistically significant when the probability value was $<0.05$.

\section{Results}

\section{Growth promotion activity of lactoferrin samples}

The in-vitro growth promotion activity of bLf and huLf preparations for three strains of Bifidobacterium spp. is shown in Table 2. Preparations of bLf obtained either commercially or isolated from mature cow's milk stimulated the growth of $B$. infantis and $B$. breve in a dose-dependent manner. When bLf was added to bifidobacteria cultures at $1-2 \mathrm{mg} / \mathrm{ml}$, acid production during the 48-h incubation period increased from $c$. 0.1 units in control cultures of $>0.40$ units $(p<0.05)$, corresponding to about a 500 -fold increase in bacterial cell numbers. Milk bLf caused only a slight increase in growth of $B$. bifidum $(\mathrm{p}<0.05)$. In contrast, bLf isolated from fresh colostrum showed no growth promotion activity for $B$. bifidum, $B$. infantis or $B$. breve. The growth of $B$. infantis appeared to be slightly inhibited by colostrum bLf (compared with control), although these differences were not statistically significant. Lactoferrin isolated from fresh milk (huLf) stimulated an increase in the growth of $B$. bifidum $(\mathrm{p}<0.05)$, but did not affect the growth of $B$. breve or $B$. infantis. In general, the maximum growth response to bLf and huLf samples was less for $B$. bifidum than that for $B$. infantis and $B$. breve $(\mathrm{p}<0.05)$.

The effect of iron saturation level of bLf and huLf samples on the in-vitro bifidobacteria growth promotion activity is shown in Table 3. Iron saturated and unsaturated forms of human transferrin (huTf) were also tested for comparison because of their similarity of Lf in structure and iron-binding capability. Native bLf isolated from unpasteurised milk which had an iron saturation level of $<10 \%$ exhibited good growth promotion activity for $B$. infantis and $B$. breve, but only slight activity for $B$. bifidum. The growth promotion activity of milk bLf did not change when the iron saturation level of bLf was increased to $30 \%$ or $100 \%$. Increasing the iron saturation levels of huLf 
Table 2. Bifidobacteria growth promotion activity of Lf preparations from bovine colostrum, bovine milk or human milk

\begin{tabular}{lcccc}
\hline & & \multicolumn{3}{c}{ Mean (SD) growth promotion activity (units) } \\
\cline { 3 - 5 } Lf sample & $\begin{array}{c}\text { Concentration } \\
(\mathrm{mg} / \mathrm{ml})\end{array}$ & B. bifidum & B. infantis & B. breve \\
\hline Control & - & $0.084(0.002)$ & $0.132(0.016)$ & $0.114(0.020)$ \\
Colostrum bLf & 0.5 & $0.083(0.002)$ & $0.064(0.016)$ & $0.114(0.007)$ \\
& 1.0 & $0.073(0.012)$ & $0.070(0.032)$ & $0.110(0.013)$ \\
& 2.0 & $0.095(0.005)$ & $0.061(0.025)$ & $0.041(0.019)$ \\
Milk bLf & 0.5 & $0.110(0.003)$ & $0.332(0.012)^{\dagger}$ & $0.313(0.069)^{\dagger}$ \\
& 1.0 & $0.130(0.006)^{\dagger}$ & $0.425(0.027)^{\dagger}$ & $0.456(0.043)^{\dagger}$ \\
Milk bLf (commercial) & 2.0 & $0.141(0.031)^{\dagger}$ & $0.600(0.006)^{\dagger}$ & $0.600(0.018)^{\dagger}$ \\
& 1.0 & $0.140(0.007)^{\dagger}$ & $0.636(0.011)^{\dagger}$ & $0.731(0.008)^{\dagger}$ \\
Milk huLf & 2.0 & $0.199(0.003)^{\dagger}$ & $0.650(0.008)^{\dagger}$ & $0.774(0.011)^{\dagger}$ \\
& 0.5 & $0.209(0.015)^{\dagger}$ & $0.103(0.012)$ & $0.067(0.006)$ \\
& 1.0 & $0.269(0.014)^{\dagger}$ & $0.103(0.010)$ & $0.052(0.008)$ \\
& 2.0 & $0.340(0.019)^{\dagger}$ & $0.143(0.013)$ & $0.073(0.004)$ \\
\hline
\end{tabular}

*Units of growth defined as mmoles of $\mathrm{NaOH}$ required to neutralise the acid produced during incubation of a bacterial culture $(4 \mathrm{ml})$ for $48 \mathrm{~h}$, with or without Lf. Results are given as the mean (SD) of at least quadruplicate samples.

†'Significantly greater than control $(p<0.05)$.

Table 3. Effect of Lf iron saturation level on bifidobacteria growth promotion activity of bovine milk Lf and human milk Lf

\begin{tabular}{|c|c|c|c|c|}
\hline \multirow[b]{2}{*}{ Test samples } & \multirow{2}{*}{$\begin{array}{c}\text { Iron } \\
\text { saturation } \\
\text { level }(\%)\end{array}$} & \multicolumn{3}{|c|}{ Mean (SD) growth promotion activity $(\mathrm{U})^{*}$} \\
\hline & & B. bifidum & B. infantis & B. breve \\
\hline Control & - & $0.076(0.003)$ & $0.172(0.045)$ & $0.096(0.052)$ \\
\hline Milk bLf & $\begin{array}{r}<10 \\
30 \\
100\end{array}$ & $\begin{array}{l}0.120(0.004)^{\dagger} \\
0.112(0.003)^{\dagger} \\
0.108(0.004)^{\dagger}\end{array}$ & $\begin{array}{l}0.324(0.016)^{\dagger} \\
0.352(0.005)^{\dagger} \\
0.344(0.009)^{\dagger}\end{array}$ & $\begin{array}{l}0.552(0.032)^{\dagger} \\
0.545(0.045)^{\dagger} \\
0.527(0.042)^{\dagger}\end{array}$ \\
\hline Milk huLf & $\begin{array}{r}<10 \\
30 \\
100\end{array}$ & $\begin{array}{l}0.247(0.008)^{\dagger} \\
0.219(0.013)^{\dagger} \\
0.209(0.004)^{\dagger}\end{array}$ & $\begin{array}{l}0.095(0.002) \\
0.112(0.003) \\
0.129(0.003)\end{array}$ & $\begin{array}{l}0.077(0.039) \\
0.093(0.009) \\
0.118(0.016)\end{array}$ \\
\hline HuTf & $\begin{array}{l}<10 \\
100\end{array}$ & $\begin{array}{ll}0.221 & (0.001)^{\dagger} \\
0.111 & (0.005)^{\dagger}\end{array}$ & $\begin{array}{l}0.214(0.039) \\
0.273(0.015)^{\dagger}\end{array}$ & $\begin{array}{l}0.027(0.001) \\
0.035(0.002)\end{array}$ \\
\hline
\end{tabular}

${ }^{*}$ Units of growth defined as mmoles of $\mathrm{NaOH}$ required to neutralise the acid produced during incubation of a bacterial culture $(4 \mathrm{ml})$ for $48 \mathrm{~h}$ with Lf samples at $1 \mathrm{mg} / \mathrm{ml}$. Results are given as the mean (SD) of at least quadruplicate samples.

${ }^{\dagger}$ Significantly greater than control $(\mathrm{p}<0.05)$.

preparations from $<10 \%$ to either $30 \%$ or $100 \%$ did not alter the growth promotion activity of huLf for $B$. bifidum or lead to growth promotion activity for $B$. infantis or $B$. breve. The huTf in both iron saturated and unsaturated forms showed growth promotional activity for $B$. bifidum, while neither form of huTf promoted the growth of $B$. breve. Only the iron saturated form of huTf promoted the growth of $B$. infantis $(\mathrm{p}<0.05)$.

\section{Binding of $L f$ to bifidobacteria cells}

Binding of biotinylated milk bLf to $B$. breve and $B$. bifidum was evaluated to determine whether the different growth promotion responses to bLf by $B$. breve and $B$. bifidum were correlated with levels of milk bLf bound to bifidobacterial cells. Preliminary studies demonstrated that binding of biotinylated bLf to bifidobacteria cells was similar at $4^{\circ} \mathrm{C}, 22^{\circ} \mathrm{C}$ and $37^{\circ} \mathrm{C}$ and reached a maximum level following incubation for 15 min (data not shown). The addition of increasing amounts of biotinylated milk bLf $(0.01-0.25 \mu \mathrm{g})$ to $10^{8}$ cells resulted in a linear increase in binding of milk $\mathrm{bLf}$ to $B$. breve and $B$. bifidum, reaching a maximum binding at $c .0 .5 \mu \mathrm{g}$ of milk bLf (Fig. 1). As shown in Fig. 1, similar binding of milk bLf was observed for $B$. breve and $B$. bifidum despite the lower growth promotion activity of milk bLf for B. bifidum (Table 2). In contrast, binding of milk bLf to a strain of enterotoxigenic $E$. coli was at least 40 -fold lower than binding to Bifidobacterium spp. (Fig. 1).

Binding of bLf from colostrum to Bifidobacterium spp. was also evaluated to determine whether differences in bifidobacteria to growth promotion activity correlated with binding of Lf to bacterial cells. Similar binding of milk bLf and colostrum bLf was observed for B. breve and B. bifidum (Fig. 2a and b), despite the lack of growth promotion activity of colostrum bLf for both $B$. bifidum and $B$. breve (Table 2 ). The addition of a 500-fold excess of unlabelled 


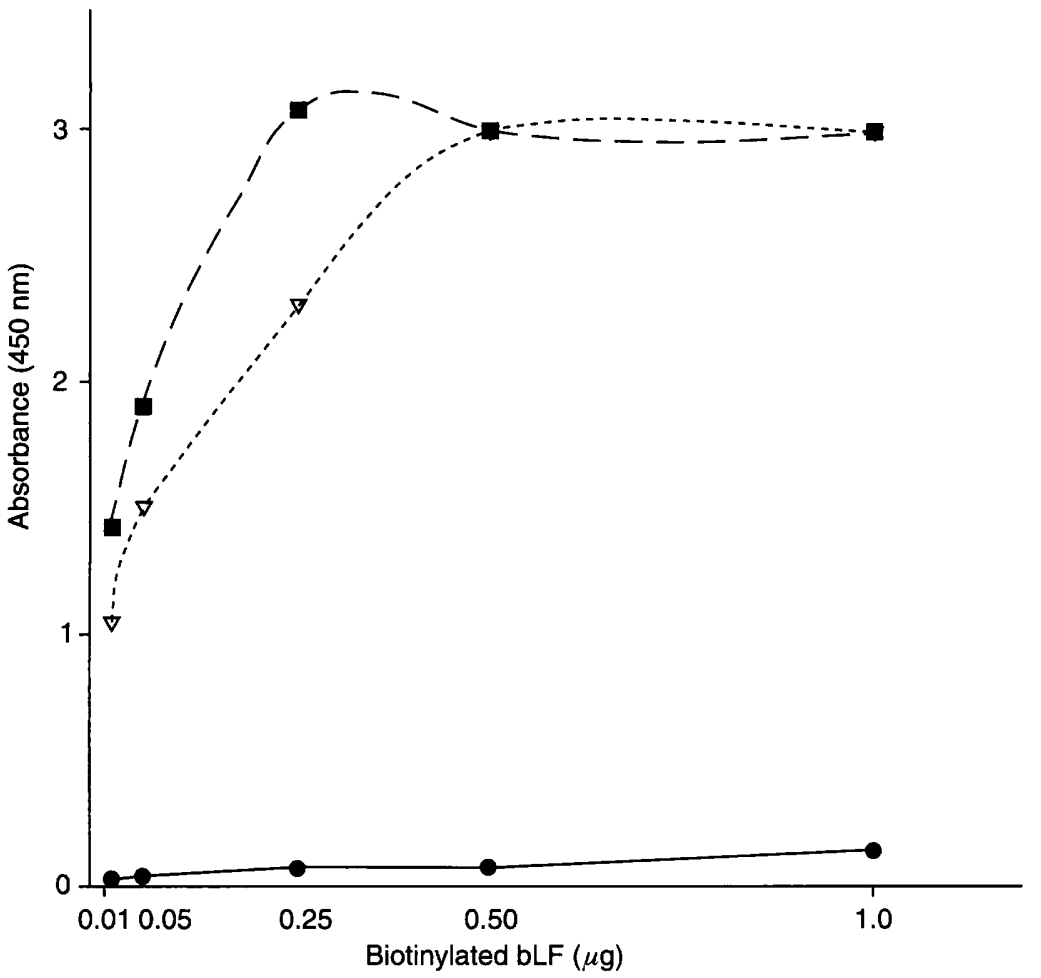

Fig. 1. Binding of biotinylated milk bLf to B. bifidum $(\cdot \nabla \cdot)$, B. breve $(--)$ and E. coli (- - ). Varying amounts of biotinylated bLf $(0.01-1.0 \mu \mathrm{g})$ were added to $10^{8}$ washed bacterial cells and incubated for $1 \mathrm{~h}$. Cell mixtures were washed and bound bLf was detected with peroxidase-labelled streptavidin. Data represent total binding of milk bLf after correction for background binding detected in the absence of biotinylated bLf from at least three separate experiments.

bLf to the standard Lf binding assay indicated that non-specific binding of biotinylated bLf to $B$. breve and $B$. bifidum was consistently $5 \%$ for milk bLf and colostrum bLf (Fig. 2).

The specificity of bLf binding to bifidobacteria cells was determined in competitive inhibition experiments performed with excess amounts (up to 10000-fold) of unlabelled Lf or heterologous proteins (Fig. 3). The presence of a 10000 -fold excess of $\alpha$-lactalbumin, $\beta$ lactoglobulin or transferrin resulted in only marginal inhibition of binding $(<20 \%)$ of milk bLf to $B$. breve and $B$. bifidum. While a 1000 -fold excess of heterologous proteins resulted in $\leqslant 20 \%$ inhibition of binding of milk bLf to $B$. breve and $B$. bifidum, the addition of a 1000 -fold excess of unlabelled milk bLf resulted in $95 \%$ inhibition of the binding of biotinylated milk bLf to bifidobacteria cells. Milk huLf inhibited the binding of biotinylated bLf, but less efficiently than inhibition by unlabelled milk bLf. The amount of unlabelled Lf needed to inhibit 50\% of the binding of biotinylated bLf to $B$. breve or $B$. bifidum was $c$. $100 \mu \mathrm{g}$ for huLf and $1 \mu \mathrm{g}$ for milk bLf.

\section{Discussion}

Although Lf was first isolated from human and bovine milk c. 35 years ago $[27,28]$, the functions of this iron- binding glycoprotein in vivo, its mechanism of action and its biological significance remain the subject of intense investigation. A number of in-vitro studies have shown that $\mathrm{Lf}$ is bacteriostatic and in some cases bactericidal for various gram-negative and gram-positive bacteria [20-23]. The wealth of in-vitro data on the antibacterial properties of $\mathrm{Lf}$ combined with the existence of relatively large amounts of $\mathrm{Lf}$ in human milk has led to speculation that $\mathrm{Lf}$ has an important role in antimicrobial host defence for the newborn infant.

A previous study reported that Lf from cow's milk also promotes the in-vitro growth of anaerobic bacteria of the genus Bifidobacterium [16]. The present study expanded the understanding of both the growth promotion activity and binding of Lf for different Bifidobacterium spp. It found that the growth of $B$. bifidum was more responsive to huLf than to bLf, while the growth of $B$. infantis and $B$. breve was promoted only by milk bLf. In addition, commercial samples of milk bLf showed the same pattern of bifidobacteria growth promotion activity as bLf from fresh milk. Surprisingly, bLf isolated from colostrum did not promote the growth of any of the three strains of bifidobacteria when tested at concentrations up to $2 \mathrm{~g} / \mathrm{L}$. It is possible that the differences observed in bifidobacterial growth promotion activity for $\mathrm{Lf}$ samples from human milk, bovine milk and bovine 


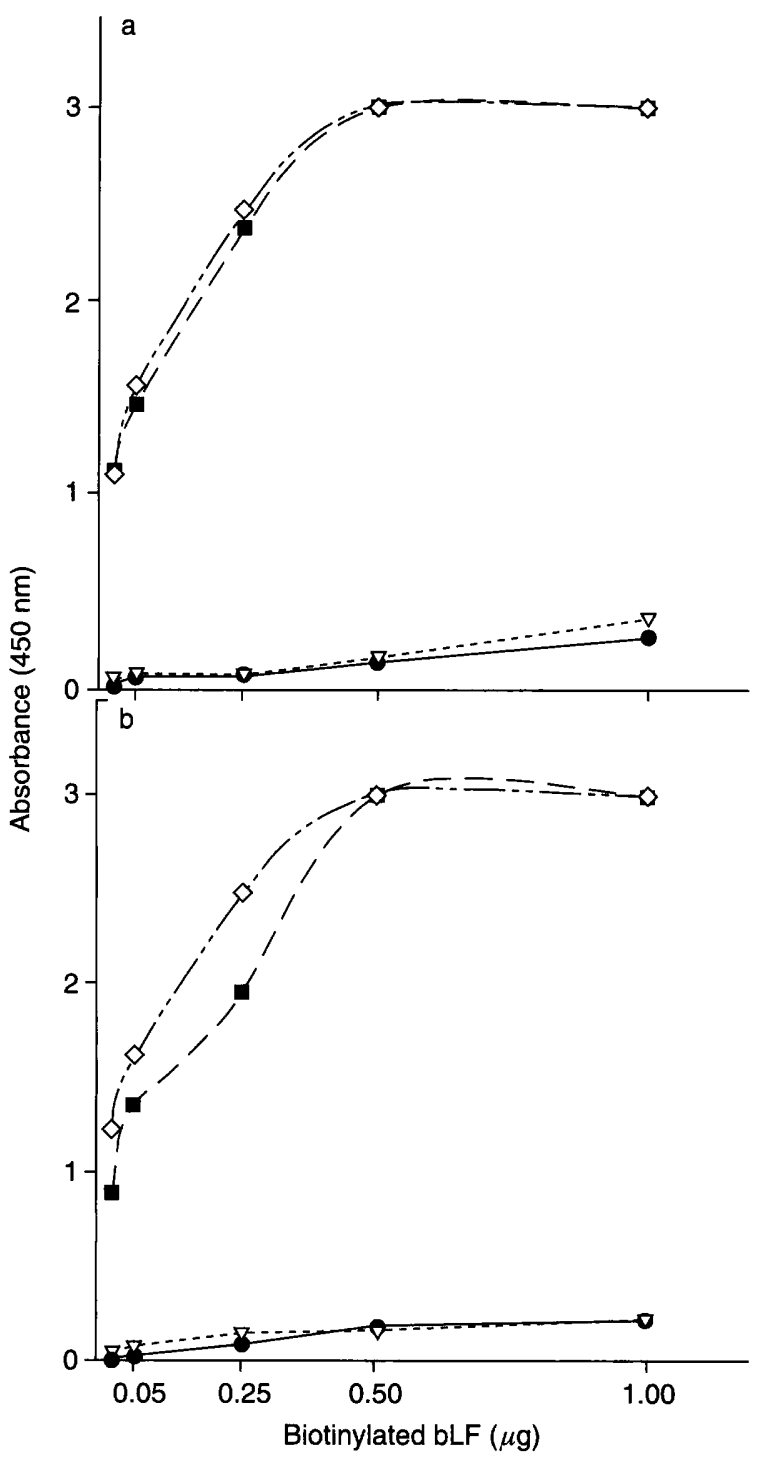

Fig. 2. Total and non-specific (NS) binding of (a) biotinylated milk bLf and (b) colostrum bLf to $B$. bifidum $\left(\cdots-\diamond_{-} \cdot\right.$, total; $--\nabla--$, NS) and $B$. breve ( - - total; -- , NS). Non-specific binding of biotinylated bLf was determined by measuring binding in the presence of a 500 -fold excess of unlabelled bLf. Subtraction of non-specific bLf binding from total bLf binding in the linear portion of the binding curves indicated that specific binding to $B$. bifidum and $B$. breve was $\geqslant 95 \%$ for both milk bLf and colostrum bLf.

colostrum are related to known differences in either the carbohydrate or amino acid content of the huLf and bLf molecules [29-31].

The antibacterial action of $\mathrm{Lf}$ is most frequently attributed to its ability to chelate iron, which in turn may restrict the availability of this essential nutrient for susceptible organisms. Reports of Lf binding by different types of bacteria [32-34] have also led to speculation that receptors for $\mathrm{Lf}$ play a role in the antibacterial action of $\mathrm{Lf}$. For example, binding of $\mathrm{Lf}$ to receptors on gram-negative bacteria may lead to destabilisation of the outer membrane, causing increased cell permeability as another antibacterial mechanism for Lf [22-24]. However, other investigators have speculated that Lf receptors may facilitate iron acquisition by certain types of bacteria [32, 33]. Although the tendency of Lf to bind non-specifically to many acidic macromolecules has led to questions regarding the existence of true receptors for $\mathrm{Lf}$ on bacterial cells, the results of the present study provide evidence that the binding of biotinylated bLf by Bifidobacterium spp. occurs in a specific receptormediated fashion. Non-specific binding was found to be $<5 \%$ of total binding and bonding of milk bLf was inhibited by homologous but not heterologous glycoproteins. The amount of inhibitor protein required to decrease binding of biotinylated bLf by $50 \%$ was at least 1000-fold lower for bLf when compared with $\alpha$ lactalbumin, $\beta$-lactoglobulin or transferrin. Although saturable binding of Lf to bifidobacteria cells was not obvious, this may be related to the tendency of Lf molecules to aggregate when present at sufficiently high concentrations, which may have caused the slight but steady increase in apparent bovine Lf binding observed during this study. The results also indicate that low levels of bacterial LPS may not interfere with Lf binding to bifidobacteria cells, as commercial milk bLf samples with high levels of LPS showed very high bifidobacteria growth promotion activity and binding to bifidobacteria cells.

These results also provide evidence that adsorption of Lf to the surface of bifidobacteria cells may be involved but is not sufficient for the growth promotion activity of Lf. Comparable binding of either milk or colostrum bLf to bifidobacteria cells was observed, despite results showing that colostrum bLf is devoid of bifidobacteria growth promotion activity. Likewise, milk bLf was shown to bind $B$. bifidum, even though it was devoid of growth promotion activity for $B$. bifidum. Unlabelled huLf inhibited the binding of biotinylated bLf in an intermediate fashion, which may be due to known structural differences reported for bLf and huLf [29-31].

The results of the present study also provide evidence that the ability of Lf to stimulate the growth of Bifidobacterium spp. is independent of the iron saturation level of Lf. High and low levels of iron saturation showed similar bifidobacteria growth promotion activity for both bLf and huLf samples. Furthermore, increases in the iron saturation level of huLf preparations did not result in growth promotional activity for $B$. infantis or $B$. breve. However, it should be recognised that iron acquisition from $\mathrm{Lf}$ may still be involved in bifidobacteria growth promotion, as iron depleted Lf could take up iron from the medium and become iron saturated before promoting growth of bifidobacteria. However, this is unlikely because it would seem that Lf binding would be necessary for iron acquisition, while the results of the present study collectively suggest a lack of correlation between binding and growth promotion activity. For example, 


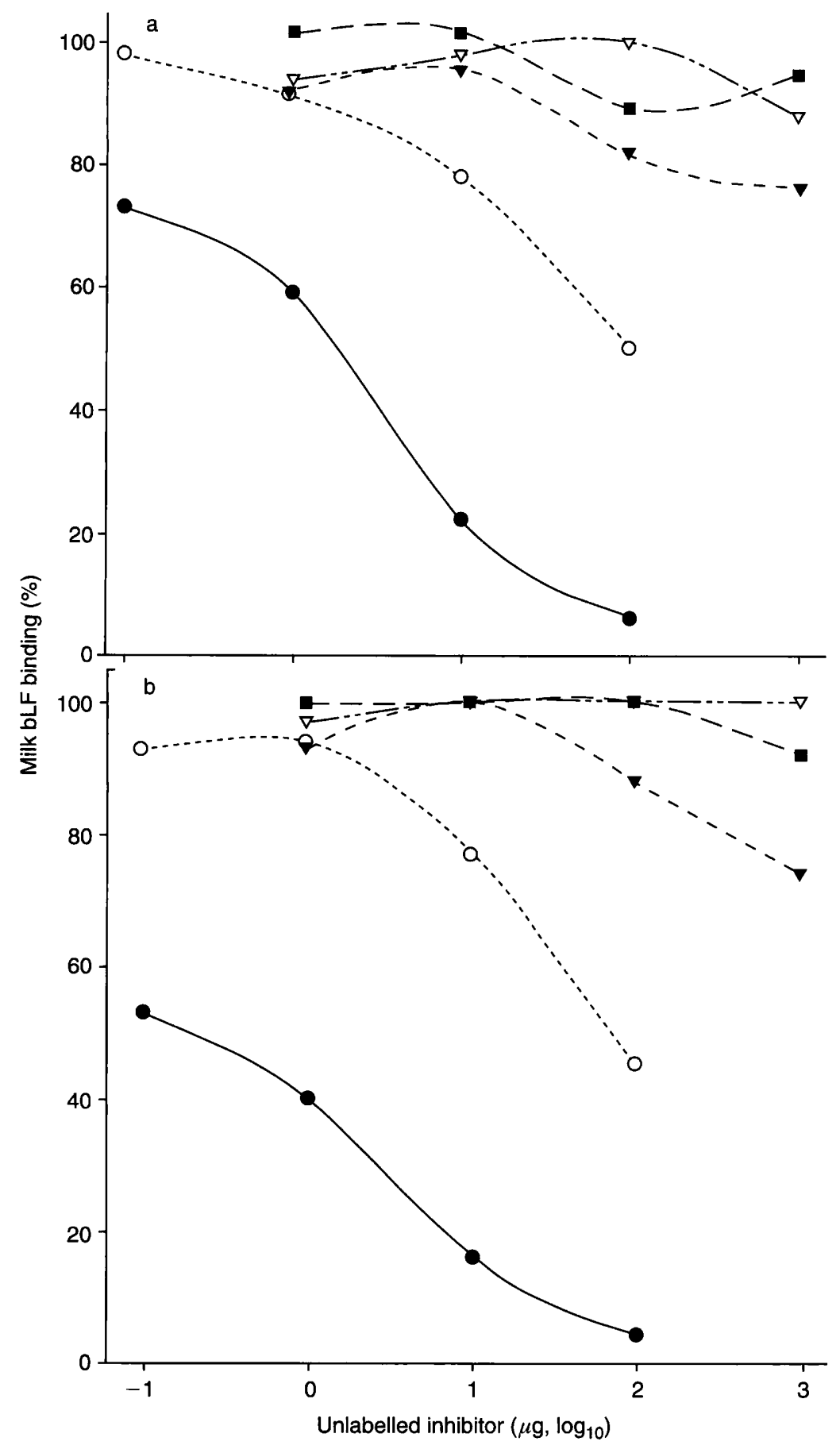

Fig. 3. Inhibition of binding of milk bLf to (a) B. bifidum and (b) B. breve by unlabelled milk bLf ( - -), milk huLf $(\cdot \circ \cdot), \beta$-lactoglobulin $(-\nabla-), \alpha$-lactalbumin $(--)$ and human apotransferrin $(\cdots-\nabla \cdots-)$. Inhibitors were preincubated with bacterial cells at levels ranging from 0.5 to $1000 \mu \mathrm{g}$ prior before measuring the binding of $0.1 \mu \mathrm{g}$ of biotinylated Lf in a standard assay with $10^{8}$ bacterial cells.

both milk bLf and colostrum bLf should bind iron from the incubation media very efficiently and have been shown to bind to bifidobacteria, yet milk bLf but not colostrum bLf promoted growth of B. bifidum or B. breve.

The ability of Lf to stimulate growth of bifidobacteria may indicate that Lf plays a role in host defence by promoting the development of a more favourable intestinal bacterial flora [2]. Comparative studies on the impact of diet on faecal flora patterns in newborn infants have found that after the intestinal flora becomes established, Bifidobacterium spp. are more predominant in the colon of breast-fed infants than in infants fed cow's milk or milk-based infant formula $[3,7,35]$. Absolute numbers of bifidobacteria are similar in formula-fed and breast-fed infants, while other types of bacteria - such as Bacteroides, Clostridium and Enterococcus spp. and Escherichia coli - are frequently present in higher numbers in infants fed milk or commercial formulas $[4,6]$. The individual species of Bifidobacterium that predominate 
in faeces of breast-fed infants vary according to the geographic location of study sites and are not markedly different from species found in formula-fed infants $[4,36]$. Both $B$. infantis and $B$. breve are commonly found in high numbers in faeces of breastfed infants, despite the negligible growth promotion of these species in these studies in response to huLf, which is present in human milk at $c .1 .2 \mathrm{mg} / \mathrm{ml}$. In addition, the high numbers of bifidobacteria found in faecal samples of infants fed formula that contains negligible quantities of Lf (present in cow's milk $\sim 0.2 \mathrm{mg} / \mathrm{ml}$ ), indicate that other factors exist in milkbased formulas that promote the growth of bifidobacteria. Indeed, both human and bovine milk have been shown to contain other factors, such as oligosaccharides, that promote the growth of Bifidobacterium spp. in vitro $[15,16,37]$. While few studies have systematically evaluated the impact of Lf on the composition of intestinal bacteria, the addition of bLf to infant formula $(1-2 \mathrm{~g} / \mathrm{L})$ has been reported to cause an increase in intestinal bifidobacteria counts when fed to adult mice [38], but not human infants [39]. A number of other factors such as macro-nutrient and iron content are likely to contribute to the regulation of the composition and metabolism of the bacterial flora in the colon.

In summary, this study has shown that Lf from human and bovine milk promotes the growth of intestinal bacteria of the genus Bifidobacterium in vitro by a mechanism that apparently does not require binding of the Lf molecule to the bifidobacterial cell surface. The growth promotion activity of $\mathrm{Lf}$ for bifidobacteria did not appear to be related to the acquisition and utilisation of iron, and Lf from human milk showed greater growth promotion activity for $B$. bifidum, while bLf was more active for $B$. infantis and $B$. breve. Additional studies are needed to define the invivo significance of the antibacterial properties and bifidobacteria growth promotion activities described in in-vitro studies on Lf from different sources.

We thank Dr Jan Nuijens for providing samples of lactoferrin from human and bovine milk.

\section{References}

1. Bullen CL, Tearle PV. Bifidobacteria in the intestinal tract of infants: an in-vitro study. J Med Microbiol 1976; 9: 335-344.

2. Modler HW, McKellar RC, Yaguchi M. Bifidobacteria and bifidogenic factors. Can Inst Food Sci Technol J 1990; 23: 29-41.

3. Balmer SE, Wharton BA. Diet and faecal flora in the newborn: breast milk and infant formula. Arch Dis Child 1989; 64: 1672-77.

4. Benno Y, Sawada K, Mitsuoka T. The intestinal microflora of infants: composition of fecal flora in breast-fed and bottle-fed infants. Microbiol Immunol 1984; 28: 975-986.

5. Mevissen-Verhage EAE, Marcelis JH, Harmsen-van Amerongen WCM, de Vos NM, Verhoef J. Effect of iron on neonatal gut flora during the first three months of life. Eur $J$ Clin Microbiol 1985; 4: 273-278.

6. Stark PL, Lee A. The microbial ecology of the large bowel of breast-fed and formula-fed infants during the first year of life. J Med Microbiol 1982; 15: 189-203.

7. Yoshioka H, Iseki K, Fujita K. Development and differences of intestinal flora in the neonatal period in breast-fed and bottlefed infants. Pediatrics 1983; 72: 317-321.

8. Feachem RG, Koblinsky MA. Interventions for the control of diarrhoeal diseases among young children: promotion of breast-feeding. Bull World Health Organ 1984; 62: 271-291.

9. Howie PW, Forsyth JS, Ogston SA, Clark A, du V Florey C. Protective effect of breast feeding against infection. $B M J 1990$; 300: $11-16$.

10. Jason JM, Nieburg $P$, Marks JS. Mortality and infectious disease associated with infant-feeding practices in developing countries. Pediatrics 1984; 74: 702-707.

11. Kovar MG, Serdula MK, Marks JS, Frasner DW. Review of the epidemiologic evidence for an association between breast feeding and infant health. Pediatrics 1984; 74: 615-638.

12. Bezkorovainy A, Topouzian N. Bifidobacterium bifidus var pennyslvanicus growth promoting activity of human milk casein and its derivatives. Int J Biochem 1981; 13: 585-590.

13. György P. A hitherto unrecognized biochemical difference between human milk and cow's milk. Pediatrics 1953; 11: 98-107.

14. Nichols JH, Bezkorovainy A, Landau W. Human colostral whey M-1 glycoproteins and their L. bifidus var. penn. growth promoting activities. Life Sci 1974; 14: 967-976.

15. Petschow BW, Talbott RD. Growth promotion activity of Bifidobacterium species by whey and casein fractions from human and bovine milk. J Clin Microbiol 1990; 28: 287-292.

16. Petschow BW, Talbott RD. Response of Bifidobacterium species to growth promoters in human and cow milk. Pediatr Res 1991; 29: 208-213.

17. Goldman AS. The immune system of human milk: antimicrobial, antiinflammatory and immunomodulating properties. Pediatr Infect Dis $J$ 1993; 12: 664-671.

18. Pickering LK, Kohl S. Human milk humoral immunity and infant defense mechanisms. In: Howell RR, Morriss FH, Pickering LK (eds) Human milk in infant nutrition and health. Springfield, IL, Charles C. Thomas. 1986: 123.

19. Sanchez L, Miguel C, Brock JH. Biological role of lactoferrin. Arch Dis Child 1992; 67: 657-661.

20. Arnold RR, Russell JE, Champion WJ, Brewer M, Gauthier JJ. Bactericidal activity of human lactoferrin: differentiation from the stasis of iron deprivation. Infect Immun 1982; 35: 792-799.

21. Bullen JJ, Rogers HJ, Leigh L. Iron-binding proteins in milk and resistance to Escherichia coli infection in infants. $B M J$ 1972; 1: 69-75.

22. Ellison RT, LaForce FM, Giehl TJ, Boose DS, Dunn BE. Lactoferrin and transferrin damage of the gram-negative outer membrane is modulated by $\mathrm{Ca}^{2+}$ and $\mathrm{Mg}^{2+} . J$ Gen Microbiol 1990; 136: 1437-1446.

23. Ellison RT, Giehl TJ. Killing of gram-negative bacteria by lactoferrin and lysozyme. J Clin Invest 1991; 88: 1080-1091.

24. Appelmelk BJ, An Y-Q, Geerts $\mathrm{M}$ et al. Lactoferrin is a lipid A-binding protein. Infect Immun 1994; 62: 2628-2632.

25. Hartree EF. Determination of protein: a modification of the Lowry method that gives a linear photometric response. Anal Biochem 1972; 48: 422-427.

26. Foley; AA, Bates GW. The purification of lactoferrin from human whey by batch extraction. Anal Biochem 1987; 162: 296-300.

27. Groves ML. The isolation of a red protein from milk. $J A m$ Chem Soc 1960; 82: 3345-3350.

28. Johanson B. Isolation of an iron-containing red protein from human milk. Acta Chem Scand 1960; 14: 510-512.

29. Pierce A, Colaivizza D, Benaissa $\mathbf{M}$ et al. Molecular cloning and sequence analysis of bovine lactotransferrin. Eur $J$ Biochem 1991; 196: 177-184.

30. Spik G, Coddevile B, Montreuil L. Comparative study of the primary structures of sero-, lacto- and ovotransferrin glycans. Biochimie 1988; 70: 1459-1469.

31. Ujiie M, Sarwar G, Peace RW, Watson D. Chemical and mouse growth tests for nutritional assessment of commercial lactoferrins. Nutr Res 1993; 13: 1087-1097.

32. Schryvers AB, Morris LJ. Identification and characterization of the human lactoferrin-binding protein from Neisseria meningitidis. Infect Immun 1988; 56: 1144-1149.

33. Schryvers AB. Identification of the transferrin- and lactoferrin- 
binding proteins in Haemophilus influenzae. $J$ Med Microbiol 1989; 29: $121-130$.

34. Visca P, Dalmastri C, Verzili D, Antonini G, Chiancone E Valenti P. Interaction of lactoferrin with Escherichia coli cells and correlation with antibacterial action. Med Microbiol Immunol 1990; 179: 323-333.

35. Mitsuoka T, Kaneuchi C. Ecology of the bifidobacteria. Am J Clin Nutr 1977; 30: 1799-1810.

36. Mevissen-Verhage EAE, Marcelis JH, DeVos MN, Harmsenvan Amerongen WCM, Verhoef J. Bifidobacterium, Bacteroides, and Clostridium spp. in fecal samples from breast-fed and bottle-fed infants with and without iron supplement. J Clin Microbiol 1987; 25: 285-289.
37. Bezkorovainy A, Grohlich D, Nichols JH. Isolation of a glycopolypeptide fraction with Lactobacillus bifidus subspecies pennsylvanicus growth-promoting activity from whole human milk casein. Am J Clin Nutr 1979; 32: 14281432.

38. Hentges DJ, Marsh WW, Petschow BW, Thal WR, Carter MK Influence of infant diets on the ecology of the intestinal tract of human flora-associated mice. J Pediatr Gastroenterol Nutr 1992; 14: 146-152.

39. Roberts AK, Chierici R, Sawatski G, Hill MJ, Volpato S, Vigi V. Supplementation of an adapted formula with bovine lactoferrin: 1. Effect on the infant faecal flora. Acta Paediatr 1992; 81: 119-124. 